\title{
EVALUATION OF ANTIHYPERLIPIDEMIC ACTIVITY OF LEAVES OF ACHYRANTHES ASPERA LINN. USING HYPERLIPIDEMIC RATS
}

\author{
SARVESH CN ${ }^{1 *}$, JENNIFER FERNANDES ${ }^{2}$
}

${ }^{1}$ Department of Pharmacology, Mallige College of Pharmacy, Bengaluru, Karnataka, India. ${ }^{2}$ Department of Pharmacology, NGSM Institute of Pharmaceutical Sciences, Mangalore, Karnataka, India. Email: cnsarvesh@yahoo.co.in

Received: 12 December 2016, Revised and Accepted: 21 January 2017

ABSTRACT

Objective: Plants have been one of the important sources of medicines since the beginning of human civilization. Achyranthes aspera Linn. belonging to family Amaranthaceae, commonly found in India. The plant is used as antiarthritic, purgative, diuretic, antimalarial, etc.

Methods: The antihyperlipidemic activity of alcoholic and aqueous extracts of leaves of $A$. aspera was evaluated using triton-induced hyperlipidemia model in albino Wistar rats. The acute toxicity study confirmed that both the extracts were found to be safe at $5000 \mathrm{mg} / \mathrm{kg}$ b.w. in female albino Wistar rats. In this model, eight groups (six animals per group) of animals were used. Group I and II were considered as saline and hyperlipidemic controls, respectively, and other groups received their respective agents (alcoholic or aqueous extract/atorvastatin/ayurvedic preparation) and all the groups received triton WR1339 (200 mg/kg b.w. i.v.) except saline control group. Serum cholesterol and triglycerides (TGs) level are estimated for the evaluation of antihyperlipidemic effects of extracts.

Results: The ethanolic extract has shown a significant reduction in serum cholesterol and TGs level indicating antihyperlipidemic potentials in the plant while aqueous extract has not shown any beneficial effect.

Conclusion: In this triton-induced hyperlipidemia model, serum and TG levels were analyzed ethanolic extract was shown antihyperlipidemic activity. Further clinical studies are compulsory to confirm the findings.

Keywords: Achyranthes aspera, High-density lipoprotein, Low-density lipoprotein, Triglyceride, Total cholesterol, Triton, Antihyperlipidemic.

(C) 2017 The Authors. Published by Innovare Academic Sciences Pvt Ltd. This is an open access article under the CC BY license (http://creativecommons. org/licenses/by/4. 0/) DOI: http://dx.doi.org/10.22159/ajpcr.2017.v10i4.16576

\section{INTRODUCTION}

Ancient medicinal herbal knowledge is trusted for its well-known uses in the prevention, diagnosis, treatment, and cure of a variety of diseases. Herbs have a defined kind of potency through which they can stimulate the human body to protect itself against the diseases. These medicinal herbs serve as a great source of remedies in the treatment of human and animal diseases.

There exists a plethora of knowledge and information and benefits of herbal drugs in our ancient literature of Ayurveda and Unani medicine. One of the earliest treatises of Indian medicine, the Charaka Samhita (1000 BC), mentions the use of over 2000 herbs for medicinal purpose. According to the WHO survey, $80 \%$ of the populations living in developing countries rely almost exclusively on traditional medicine for their primary health care needs.

Exploration of the chemical constituents of the plants and pharmacological screening may provide us the basis for developing the leads for development of novel agents [1].

This shows a need for planned activity guided phytopharmacological evaluation of herbal drugs. Achyranthes aspera Linn. is an annual, stiff erect herb, about 0.3-0.9 m height and found commonly as a weed throughout India. Atherosclerosis vascular disease is the leading cause of morbidity and mortality in the United States, accounting for more than one-third of all deaths each year. At any one time, 12 million Americans have coronary heart disease, 4 million have had strokes, and millions more have a significant claudication from peripheral arterial disease. Dyslipidemia is the most prevalent and important modifiable risk factor for atherosclerosis, affecting one in two (100 million) US adults [2].

A. aspera Linn. is used in indigenous system of medicine such as antibacterial, antiviral, anticancer, antioxidant, anti-inflammatory, and antiarthritic activity [3]. Hence, the present study is undertaken to evaluate the antihyperlipidemic activity of the ethanolic and aqueous extracts of the leaves of $A$. aspera at two different dose levels.

\section{METHODS}

List of chemicals used

- Cholesterol (Burgoyne Burbidges and Co., Mumbai)

- Coconut oil (Surya Industries, Udupi)

- Ayurvedic preparation (Lean Heal) (the Arya Vaidya Pharmacy, Kerala)

- Lipid profile kit for cholesterol, triglyceride (TG), and high-density lipoprotein (HDL) (AGAPPE Diagnostic Ltd.)

- Atorvastatin (Tonact-10, Lupin Pharmaceuticals, Jammu).

Collection and authentication of plant material

The leaves of "A. aspera Linn." were collected from local area in and around Mangalore, in the month of June-July. It was authenticated by Dr. Noeline J. Pinto, HOD, Department of Botany, St. Agnes College, Mangalore. Thus, obtained leaves were cleaned from dust and other materials, and then, it was dried under the shade for 15 days. Moreover, the dried leaves were pulverized in an electric grinder and passed through Sieve No. 40. The powdered materials were subjected to maceration.

Preparation of extracts (ethanolic and aqueous)

The powder was soaked in $90 \%$ ethanol and distilled water separately for 6 days, stirring of the mixture was done thrice daily. The syrupy consistency materials obtained were concentrated by evaporating using the water bath until semisolid consistency was obtained. These ethanolic extracts (reddish-brown color) and aqueous extracts (dark greenish color) were having the weight about 35.5 and $101 \mathrm{~g}$, respectively, and stored in a desiccator. The ethanolic extract was dissolved in water using tween 80 and the aqueous extract was freely soluble in the water. 
Preliminary qualitative phytochemical analysis $[4,5]$

The ethanolic and aqueous extracts of leaves of $A$. aspera were subjected to qualitative examination for different phytoconstituents such as alkaloids, carbohydrates, flavonoids, glycosides, saponins, terpenoids, and steroids using standard methods.

1. Alkaloids
a. Dragendroff's test
b. Hager's test
c. Wagner's test
d. Mayer's test.

2. Carbohydrates
a. Molisch test
b. Benedict's test
c. Fehling's test
d. Anthrone test.

3. Flavonoids

a. Shinoda test.

4. Triterpenoids

a. Liebermann-Burchard's test

5. Steroids

a. Liebermann-Burchard's test.

6. Proteins
a. Biuret's test

b. Millon's test.

7. Saponins

8. Tannins

a. Gelatin test.

9. Glycosides
a. Cardiac glycosides
b. Saponin glycosides
c. Anthraquinone glycosides.

\section{Acute toxicity studies [6,7]}

Acute toxicity study was conducted to determine the median lethal dose $50 \%\left(\mathrm{LD}_{50}\right)$ of the ethanolic and aqueous leaf extracts of the plant A. aspera. The acute toxicity study was carried out in adult female albino rats by "up and down" method and OECD guidelines 425 . The limit test was used (the limit test is primarily used in situations where the experimenter has information indicating that the test material is likely to be nontoxic, i.e., having toxicity below regulatory limit doses).

The limit test is a sequential test that uses a maximum of five animals. A test dose of $2000 \mathrm{mg} / \mathrm{kg}$, or exceptionally $5000 \mathrm{mg} / \mathrm{kg}$, may be used. One animal dosed at the test dose. If the animal survived, four additional animals dosed sequentially so that a total of five animals were tested. In case three animals die, the limit test is terminated and main test is performed if $\mathrm{LD}_{50}$ is greater than the test dose, three or more animals will survive. However, all the dosed five animals were survived at $2000 \mathrm{mg} / \mathrm{kg}$. The alcoholic extract was dissolved in water using tween 80 and prepared a concentration of $200 \mathrm{mg} / \mathrm{ml}$ and aqueous extract was dissolved in water and prepared a concentration of $500 \mathrm{mg} / \mathrm{ml}$. The test dose is given to overnight fasted animals and continuously observed for 2-3 hrs for general behavioral, neurological, autonomic profiles then occasionally checked for the next $24 \mathrm{hrs}$ and after $48 \mathrm{hrs}$ (initial observation period). Further, animals were observed for 8 days (to check any late deaths). The limit test procedure of $5000 \mathrm{mg} / \mathrm{kg}$ was carried out according to OECD guidelines and found all the animals were well tolerated and survived. From this, one can conclude that the $\mathrm{LD}_{50}$ is more than $5000 \mathrm{mg} / \mathrm{kg}$ body weight.

Ethanolic and aqueous leaves extracts of the plant $A$. aspera dissolved in water using tween 80 and in water, respectively. The extracts were given initially to two separate animals and later to two different groups each group containing four animals (total five animals). There was no mortality and no signs of toxicity and the extracts were found to be safe at this dose level. The literature survey revealed that the $\mathrm{LD}_{50}$ is up to $8000 \mathrm{mg} / \mathrm{kg}$ [8].

All the experiments were performed within the guidelines of the Institutional Animal Ethics Committee of K.S. Hegde Medical Academy, Deralakatte, Mangalore. The result of acute toxicity study revealed that the ethanolic and aqueous extracts of leaves of the plant $A$. aspera is safe at maximum dose of $5000 \mathrm{mg} / \mathrm{kg}$ body weight in rats.

\section{Selection of animals}

Rats are excellent subjects for toxicological studies (according to OECD guidelines). Wistar albino rats of either sex weighing between 150 and 200 g were obtained from NGSMIPS, Paneer, Deralakatte, Mangalore. These animals were used for the evaluation of antihyperlipidemic activity.

The animals were stabilized for 1 week; they were maintained in standard condition at room temperature; $60 \pm 5 \%$ relative humidity and 12 hrs lightdark cycle. They had been given standard pellet diet supplied by Hindustan Lever Co., Mumbai and water ad libitum throughout the course of the study. The cleaning and sanitation work done alternative days and paddy husk was provided as bedding material, which was changed everyday. The cages and water bottles were regularly cleaned. The animals were handled gently to avoid giving them too much stress, which could result in an increased adrenal output. Institutional Animal Ethics Committee permission for the project has been taken (KSHEMA/AEC/072/2008).

\section{Selection of doses}

For the assessment of all the biological activities, two dose levels of ethanolic and aqueous extracts were chosen in such a way that higher dose was approximately one-tenth of the maximum dose concluded during the acute toxicity studies, and lower dose was $50 \%$ of the onetenth dose, i.e., 500 and $250 \mathrm{mg} / \mathrm{kg}$ body weight, respectively. The atorvastatin dose was taken $30 \mathrm{mg}$ as normal human adult dose, which was $2.70 \mathrm{mg} / \mathrm{kg}$ b.w.as rat dose according to the conversion chart [5]. The ayurvedic preparation (Lean Heal) was calculated in accordance with volume to weight ratio, the dose specified on the label was one teaspoon as adult human dose, the weight of one teaspoon ( $4 \mathrm{ml}$ ) was $5.20 \mathrm{~g}$. This dose in rats was $468 \mathrm{mg} / \mathrm{kg}$ b.w. according to conversion chart [5]. The ayurvedic preparation (Lean Heal) is a polyherbal preparation having the coposition of Haritaki, Amalaki, Vibeethaki, Asanam, Draksha, Annabhedi Sinduram, and flavored syrup (q.s.).

\section{Statistical analysis}

The data were represented as mean \pm standard deviation (SD). The data of antihyperlipidemic activity of leaves of $A$. aspera were analyzed by one-way analysis of variance (ANOVA) followed by Dunnett's test for comparison of data in between the groups. $\mathrm{p}<0.05$ was considered as statistically significant.

\section{Triton-induced hyperlipidemia $[9,10]$}

Effect of aqueous and ethanolic extracts of leaves of A. aspera on triton-induced hyperlipidemia

Wistar albino rats of either sex weighing in between 150 and $250 \mathrm{~g}$ were divided into eight groups containing six animals in each group. After dividing the animals into different groups, they were kept in separate labeled cages. The rats were divided into the following groups:

- Group I: Served as control (saline only)

- Group II: Served as hyperlipidemic control - Received triton $(200 \mathrm{mg} / \mathrm{kg} \mathrm{b.w}$ ) dissolved in $0.15 \mathrm{M} \mathrm{NaCl}$

- Group III: Received triton (200 mg/kg b.w) dissolved in $0.15 \mathrm{M} \mathrm{NaCl}$ + ethanolic extract $250 \mathrm{mg} / \mathrm{kg}$ b.w.

- Group IV: Received triton (200 mg/kg b.w) dissolved in $0.15 \mathrm{M} \mathrm{NaCl}$ + ethanolic extract $500 \mathrm{mg} / \mathrm{kg}$ b.w.

- Group V: Received triton $(200 \mathrm{mg} / \mathrm{kg} \mathrm{b.w})$ dissolved in $0.15 \mathrm{M} \mathrm{NaCl}$ + aqueous extract $250 \mathrm{mg} / \mathrm{kg}$ b.w.

- Group VI: Received triton $(200 \mathrm{mg} / \mathrm{kg} \mathrm{b.w})$ dissolved in $0.15 \mathrm{M} \mathrm{NaCl}$ + aqueous extract $500 \mathrm{mg} / \mathrm{kg}$ b.w.

- Group VII: Received triton (200 mg/kg b.w) dissolved in $0.15 \mathrm{M} \mathrm{NaCl}$ + ayurvedic preparation (Lean Heal) $468 \mathrm{mg} / \mathrm{kg}$ b.w.

- Group VIII: Received triton (200 mg/kg b.w) dissolved in 0.15M NaCl + atorvastatin $2.70 \mathrm{mg} / \mathrm{kg}$ b.w.

\section{Procedure}

The rats were fasted for $18 \mathrm{hrs}$ and were injected through tail vein with $200 \mathrm{mg}$ triton WR1339 (isooctyl-polyoxyethylene phenol)/kg 
dissolved in $0.15 \mathrm{M} \mathrm{NaCl}$. The saline given to control group, for other groups respective extracts/atorvastatin/ayurvedic preparation were administered orally simultaneously with triton. The second dose was administered to the animals after $20 \mathrm{hrs}$, fasting was continued during the post triton period. The alcoholic and aqueous extracts were prepared as $100 \mathrm{mg} / \mathrm{ml}$ concentration for the oral dosing to the animals. The ayurvedic preparation (Lean Heal) had a free-flowing syruplike consistency, hence was easily dosed orally using the oral gavage. Atorvastatin was dissolved in water and orally dosed using the oral gavage. Blood was withdrawn using the heparinized capillaries from the retro-orbital sinus post triton administration, i.e., after $0 \mathrm{hr}, 24 \mathrm{hrs}$, and $48 \mathrm{hrs}$. The serum was obtained after centrifuging the blood, which was used to estimate the concentration of biochemical parameters using the semi autoanalyser and relevant lipid profile kits. Thus, obtained data are tabulated and checked for the statistical significance of the results using the statistical tools such as one-way ANOVA. Finally, Dunnett's test was applied to find out the difference between groups.

\section{Analysis of serum biochemical parameters}

- Quantitative determination of TGs (glycerol-3-phosphate oxidaseperoxidase-antiperoxidase [PAP]-ESPAS methodology) [11-13]

- Quantitative determination of total cholesterol (TC) (cholesterol oxidase-PAP methodology) [14]

- Quantitative determination of HDL cholesterol (Precipitation method) [13]

- Estimation of low-density lipoprotein cholesterol [14,15].

\section{RESULTS}

\section{Acute toxicity study}

The ethanolic and aqueous extracts of leaves of $A$. aspera were found to be safe at the maximum dose of $5000 \mathrm{mg} / \mathrm{kg}$ body weight (p.o.). General behaviors, neurological, autonomic profiles were found to be normal.

\section{Antihyperlipidemic activity}

The evaluation of antihyperlipidemic activity of both ethanolic and aqueous extracts of leaves of $A$. aspera was carried out by successfully employing the triton-induced hyperlipidemia model. The serum cholesterol and TG levels were estimated in the triton-induced hyperlipidemic rats during synthesis and excretory phases of the experimental period. The results are tabulated.

\section{Cholesterol}

- Serum cholesterol levels of different groups of animals during the study period are given in Table 1 and presented in Fig. 1. These observations were tabulated as mean $( \pm \mathrm{SD})$, serum cholesterol levels of hyperlipidemic control rats were found to be $48.45 \pm 7.571 \mathrm{mg} / \mathrm{dl}$ at $0 \mathrm{hr}$, which was increased to $226.1 \pm 14.96 \mathrm{mg} / \mathrm{dL}$ at $24 \mathrm{hrs}$ after triton administration (synthesis phase) and then was reduced to $150.7 \pm 24.77 \mathrm{mg} / \mathrm{dL}$ after $48 \mathrm{hrs}$ of triton administration (excretory phase).

- The atorvastatin-treated rats showed mean \pm SD serum cholesterol levels of $58.75 \pm 7.483 \mathrm{mg} / \mathrm{dL}$ at $0 \mathrm{hr}$, which was increased to $243.8 \pm 12.66 \mathrm{mg} / \mathrm{dL}$ after $24 \mathrm{hrs}$ and was reduced to $139.5 \pm 5.615 \mathrm{mg} / \mathrm{dL}$ after $48 \mathrm{hrs}$ of triton administration, which was found to be similar to that of hyperlipidemic control group. This indicates that atorvastatin was not able to inhibit the rise of the serum cholesterol levels during synthesis phase of triton-induced hyperlipidemia model.

- The ethanolic extract (250 and $500 \mathrm{mg} / \mathrm{kg}$ )-treated rats had shown mean \pm SD serum cholesterol levels of $54.23 \pm 7.104$ and $50.00 \pm 11.97 \mathrm{mg} / \mathrm{dL}$ at $0 \mathrm{hr}$, which was increased to $196.5 \pm 21.73$ and $108.7 \pm 21.38 \mathrm{mg} / \mathrm{dL}$ after $24 \mathrm{hrs}$ and reduced to $162.2 \pm 19.84$ and $90.13 \pm 17.14 \mathrm{mg} / \mathrm{dL}$ after $48 \mathrm{hrs}$ of triton administration, respectively. This was found to be significantly lower than the hyperlipidemic control group. This indicates the dose-dependent action of extract on the serum cholesterol levels of the triton-induced hyperlipidemic rats.

Table 1: The effect of extracts on the serum cholesterol levels $(\mathrm{mg} / \mathrm{dl})$ in triton-induced hyperlipidemia

\begin{tabular}{llll}
\hline S.No. & Group & \multicolumn{2}{l}{ Serum cholesterol level (mg/dL) on day (Mean \pm SD) } \\
\cline { 3 - 4 } & & $\mathbf{0 ~ h r}$ & $\mathbf{2 4} \mathbf{~ h r s}$ \\
\hline 1 & Saline control & $48.37 \pm 7.446$ & $52.88 \pm 5.856^{\mathrm{b} * *}$ \\
2 & Hyperlipidemic control & $48.45 \pm 7.571$ & $226.1 \pm 14.96^{\mathrm{a}}$ \\
3 & Ethanolic extract 250 & $54.23 \pm 7.104$ & $196.5 \pm 21.73^{\mathrm{a}, \mathrm{b} *}$ \\
4 & Ethanolic extract 500 & $50.00 \pm 11.97$ & $108.7 \pm 21.38^{\mathrm{a}, \mathrm{b} * *}$ \\
5 & Aqueous extract 250 & $51.40 \pm 7.702$ & $259.4 \pm 18.19^{\mathrm{a} \#}$ \\
6 & Aqueous extract 500 & $46.78 \pm 4.679$ & $198.6 \pm 13.24^{\mathrm{a}, \mathrm{b} *}$ \\
7 & Ayurvedic preparation & $53.83 \pm 5.067$ & $284.1 \pm 14.27^{\mathrm{a}, \mathrm{b} \#}$ \\
8 & Atorvastatin (standard) & $58.75 \pm 7.483$ & $243.8 \pm 12.66^{\mathrm{a}}$ \\
\hline
\end{tabular}

${ }^{* * *} \mathrm{p}<0.001,{ }^{* *} \mathrm{p}<0.01,{ }^{*} \mathrm{p}<0.05$ (When compared with hyperlipidemic control), ${ }^{\mathrm{a}} \mathrm{p}<0.05$ (When compared with saline control), ${ }^{\mathrm{b}} \mathrm{p}<0.05$ (When compared with atorvastatin). $\#$ p $<0.01$ (significant high TC than hyperlipidemic group); $\mathrm{n}=6$. TC: Total cholesterol, SD: Standard deviation

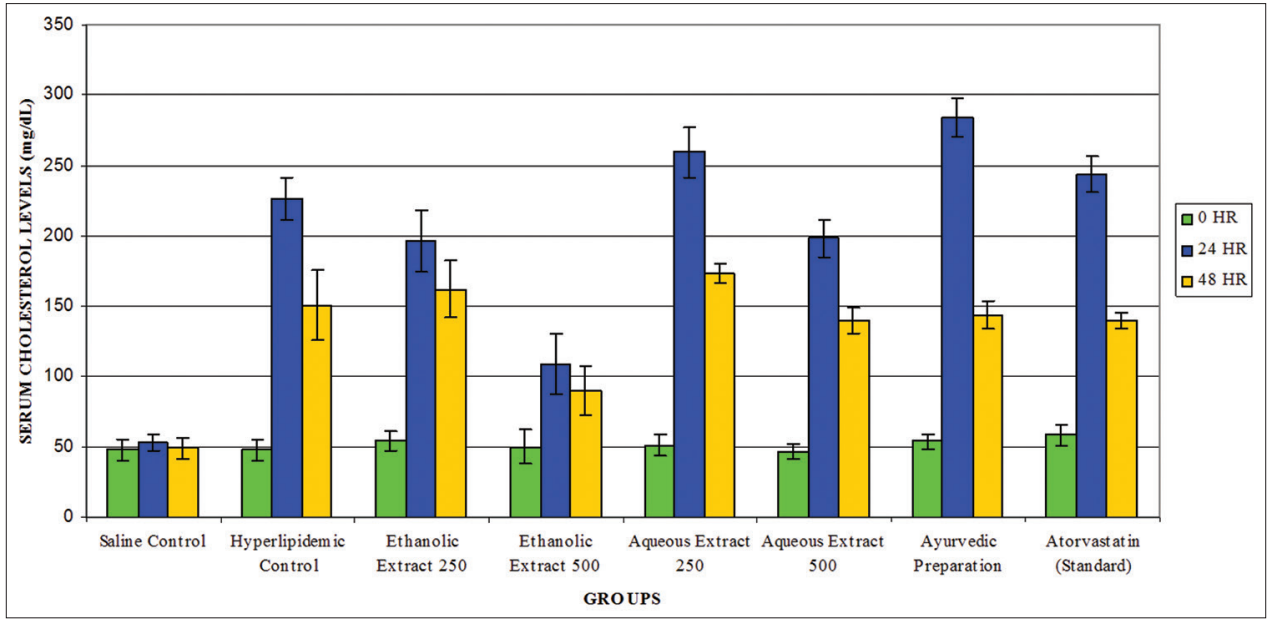

Fig. 1: The serum cholesterol levels $(\mathrm{mg} / \mathrm{dl})$ in triton-induced hyperlipidemia. The values are represented as mean \pm standard deviation 
- The aqueous extract (250 and $500 \mathrm{mg} / \mathrm{kg}$ )-treated rats had shown mean \pm SD serum cholesterol levels of $51.40 \pm 7.702$ and $46.78 \pm 4.679 \mathrm{mg} / \mathrm{dL}$ at $0 \mathrm{hr}$, which was increased to $259.4 \pm 18.19$ and $198.6 \pm 13.24 \mathrm{mg} / \mathrm{dL}$ after $24 \mathrm{hrs}$ and reduced to $173.4 \pm 6.773$ and $139.7 \pm 9.728 \mathrm{mg} / \mathrm{dL}$ at $48 \mathrm{hrs}$ after triton administration, respectively. This was found to be similar to that of hyperlipidemic control group. The aqueous extract $(500 \mathrm{mg} / \mathrm{kg})$-treated rats had the serum cholesterol levels less than that of the hyperlipidemic control group after $24 \mathrm{hrs}$ of triton injection. However, it was not able to control the serum cholesterol levels significantly lower than the hyperlipidemic control group. This indicates that aqueous extract at the dose of 250 and $500 \mathrm{mg} / \mathrm{kg}$ was not able to significantly reduce the serum cholesterol levels.

- The ayurvedic preparation (Lean Heal) treated rats showed mean \pm SD serum cholesterol levels of $53.83 \pm 5.067 \mathrm{mg} / \mathrm{dL}$ at $0 \mathrm{hr}$, which was increased to $284.1 \pm 14.27 \mathrm{mg} / \mathrm{dL}$ after $24 \mathrm{hrs}$ and was reduced to $143.6 \pm 9.904 \mathrm{mg} / \mathrm{dL}$ after $48 \mathrm{hrs}$ of triton administration, which was found to be similar to that of hyperlipidemic control group. This indicates that ayurvedic preparation was not able to reduce the serum cholesterol levels in triton-induced hyperlipidemia model.

- The normal saline control rats had retained the serum cholesterol levels uniformly during the experiment.

TG

- Serum TG levels of different groups of animals during the study period are given in Table 2 and presented in Fig. 2. These observations were tabulated as mean $\pm \mathrm{SD}$, serum TG levels of hyperlipidemic control rats were found to be $52.73 \pm 6.929 \mathrm{mg} / \mathrm{dL}$ at $0 \mathrm{hr}$, which was increased to $389.8 \pm 19.43 \mathrm{mg} / \mathrm{dL}$ at $24 \mathrm{hrs}$ after triton administration (synthesis phase) and then reduced to $176.1 \pm 10.43 \mathrm{mg} / \mathrm{dL}$ after $48 \mathrm{hrs}$ of triton administration (excretory phase).

- The atorvastatin-treated rats showed mean \pm SD serum TG levels of $56.77 \pm 10.64 \mathrm{mg} / \mathrm{dL}$ at $0 \mathrm{hr}$, which was increased to $371.7 \pm 23.35 \mathrm{mg} / \mathrm{dL}$ after $24 \mathrm{hrs}$ and was reduced to
$190.3 \pm 18.24 \mathrm{mg} / \mathrm{dL}$ after $48 \mathrm{hrs}$ of triton administration, which was found to be similar to that of hyperlipidemic control group. This indicates that atorvastatin was not able to inhibit the rise of the serum TG levels during synthesis phase of triton induced hyperlipidemic model.

- The ethanolic extract ( 250 and $500 \mathrm{mg} / \mathrm{kg}$ ) treated rats had shown mean \pm SD serum TG levels of $49.75 \pm 3.573$ and $60.22 \pm 10.03 \mathrm{mg} / \mathrm{dL}$ at $0 \mathrm{hr}$, which was increased to $362.8 \pm 22.76$ and $350.3 \pm 28.33 \mathrm{mg} / \mathrm{dL}$ after $24 \mathrm{hrs}$ and reduced to $192.5 \pm 17.92$ and $198.3 \pm 16.71 \mathrm{mg} / \mathrm{dL}$ at $48 \mathrm{hrs}$ after triton administration, respectively. The ethanolic extract at $250 \mathrm{mg} / \mathrm{kg}$ was not able to control the serum TG levels, but at the dose of $500 \mathrm{mg} / \mathrm{kg}$, it was able to show a significant decrease in serum TG levels in comparison with hyperlipidemic control group. This indicates that the ethanolic extract at a dose of $500 \mathrm{mg} / \mathrm{kg}$ was able to significantly reduce the serum TG levels.

- The aqueous extract (250 and $500 \mathrm{mg} / \mathrm{kg}$ ) treated rats had shown mean \pm SD serum TG levels of $62.15 \pm 8.446$ and $59.33 \pm 8.268 \mathrm{mg} / \mathrm{dL}$ at $0 \mathrm{hr}$, which was increased to $393.6 \pm 17.95$ and $359.6 \pm 21.58 \mathrm{mg} / \mathrm{dL}$ after $24 \mathrm{hrs}$ and reduced to $210.1 \pm 12.16$ and $205.8 \pm 16.07 \mathrm{mg} / \mathrm{dL}$ at $48 \mathrm{hrs}$ after triton administration, respectively. This was found to be similar to that of hyperlipidemic control group. The aqueous extract $(500 \mathrm{mg} / \mathrm{kg})$-treated rats had the serum TG levels less than that of the hyperlipidemic control group after 24 hrs of triton injection. However, it was not able to control the serum TG levels significantly lower than the hyperlipidemic control group. This indicates that aqueous extract at the dose of 250 and $500 \mathrm{mg} / \mathrm{kg}$ was not able to significantly reduce the serum TG levels.

- The ayurvedic preparation (Lean Heal) treated rats showed mean $\pm S D$ serum TG level of $49.62 \pm 6.755 \mathrm{mg} / \mathrm{dL}$ at $0 \mathrm{hr}$, which was increased to $340.1 \pm 21.07 \mathrm{mg} / \mathrm{dL}$ after $24 \mathrm{hrs}$ and was reduced to $215.9 \pm 15.80 \mathrm{mg} / \mathrm{dL}$ after $48 \mathrm{hrs}$ of triton administration. This was found to be lower serum TG levels than the hyperlipidemic control group. This indicates that ayurvedic preparation was able to reduce the serum TG level in triton-induced hyperlipidemia.

Table 2: Mean values of the serum TG levels (mg/dl) in triton-induced hyperlipidemia

\begin{tabular}{|c|c|c|c|c|}
\hline \multirow[t]{2}{*}{ S.No. } & \multirow[t]{2}{*}{ Group } & \multicolumn{3}{|c|}{ Serum TG level $(\mathrm{mg} / \mathrm{dL})$ on day $($ Mean \pm SD) } \\
\hline & & $\mathbf{0 ~ h r}$ & $24 \mathrm{hrs}$ & $48 \mathrm{hrs}$ \\
\hline 1. & Saline control & $58.92 \pm 8.152$ & $65.10 \pm 11.17^{\mathrm{b} * *}$ & $59.62 \pm 7.530^{\mathrm{b} * *}$ \\
\hline 2. & Hyperlipidemic control & $52.73 \pm 6.929$ & $389.8 \pm 19.43^{\mathrm{a}}$ & $176.1 \pm 10.43^{\mathrm{a}}$ \\
\hline 3. & Ethanolic extract 250 & $49.75 \pm 3.573$ & $362.8 \pm 22.76^{a}$ & $192.5 \pm 17.92^{\mathrm{a}}$ \\
\hline 4. & Ethanolic extract 500 & $60.22 \pm 10.03$ & $350.3 \pm 28.33^{a *}$ & $198.3 \pm 16.71^{\mathrm{a}}$ \\
\hline 5. & Aqueous extract 250 & $62.15 \pm 8.446$ & $393.6 \pm 17.95^{\mathrm{a}}$ & $210.1 \pm 12.16^{\mathrm{a \#}}$ \\
\hline 6. & Aqueous extract 500 & $59.33 \pm 8.268$ & $359.6 \pm 21.58^{\mathrm{a}}$ & $205.8 \pm 16.07^{\text {a\# }}$ \\
\hline 7. & Ayurvedic preparation & $49.62 \pm 6.755$ & $340.1 \pm 21.07^{\mathrm{a} * *}$ & $215.9 \pm 15.80^{\mathrm{a}, \mathrm{bt}}$ \\
\hline 8. & Atorvastatin (Standard) & $56.77 \pm 10.64$ & $371.7 \pm 23.35^{\mathrm{a}}$ & $190.3 \pm 18.24^{\mathrm{a}}$ \\
\hline
\end{tabular}

${ }^{* * *} \mathrm{p}<0.001,{ }^{* *} \mathrm{p}<0.01,{ }^{*} \mathrm{p}<0.05$ (when compared with hyperlipidemic control), ${ }^{\mathrm{a}} \mathrm{p}<0.05$ (when compared with saline control), ${ }^{b} \mathrm{p}<0.05$ (when compared with atorvastatin), $" \mathrm{p}<0.01$ (significant high TC than hyperlipidemic group); $\mathrm{n}=6$. TC: Total cholesterol, TG: Triglyceride

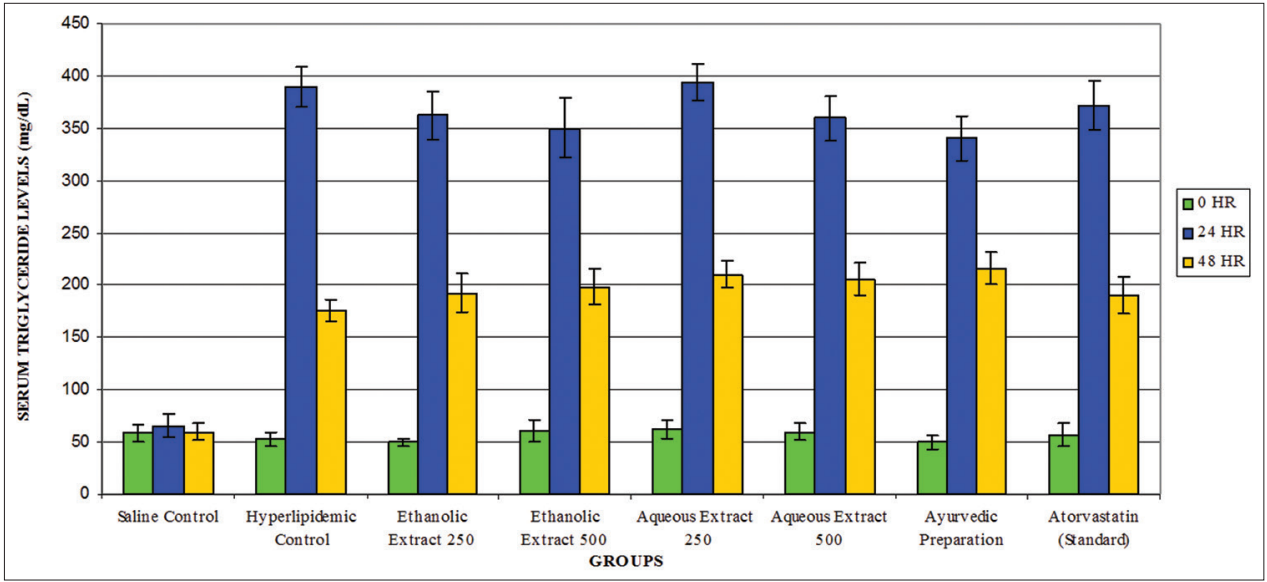

Fig. 2: The serum triglyceride levels $(\mathrm{mg} / \mathrm{dl})$ in triton-induced hyperlipidemia. The values are represented as mean \pm standard deviation 
- The normal saline control rats had retained the serum TG levels uniformly during the experiment.

\section{DISCUSSION}

Triton acts as a surfactant and suppresses the action of lipases to block the uptake of lipoproteins from circulation by extrahepatic tissues, resulting into increased blood lipid concentration [15]. The biphasic nature of triton-induced hyperlipidemia is helpful in understanding the mode of action of hypolipidemia agents. Drugs interfering with lipid biosynthesis or uptake will be active in the synthesis phase and metabolism will be active in the excretory phase. In the present study, the methanol extracts of three plants reduced the cholesterol and TGs in a manner similar to the reduction facilitated by atorvastatin.

The dried and powdered of $A$. aspera Linn. leaves was subjected to soxhlet extraction with $90 \%$ ethanol. The yield of the extract was $10 \% \mathrm{w} / \mathrm{w}$. Phytochemical analysis of the ethanolic extract showed different phytoconstituents, namely, glycosides, phytosterols, triterpenoids, alkaloids, and flavonoids. Glycosides, triterpenoids, saponins, alkaloids, and flavonoids are known to have antihyperlipidemic property. It has been well established that nutrition plays an important role in the etiology of hyperlipidemia and atherosclerosis $[16,17]$.

A. aspera has been shown to decrease the serum as well as liver levels of lipids and enhanced the excretion of bile acids. The alcoholic extract of A. aspera contains glycosides of oleanolic acid (saponin A and B) with steroidal nucleus. It has been reported that cardiac stimulant and diuretic activity of the saponins from this plant. The lipid-lowering activity of $A$. aspera may contribute to these pharmacological properties. Hypocholesterolemic effect of $A$. aspera may be in part due to its action on fecal excretion of bile acids which may regulate cholesterol homeostasis [18-20]. The detailed study is further required in clinical aspects and molecular level to prove the aqueous and ethanolic extract of $A$. aspera to reduce the cholesterol and TG levels. Furthermore, to prevent the cardiovascular and cerebrovascular diseases in clinical is needed.

\section{CONCLUSION}

The obesity epidemic in the India has led to a high-priority search for Indian herbal therapies that work effectively. Although there is no magic bullet available among Indian herbs that can melt the kilograms of fat in a short period, there is a need to create awareness regarding the evidence for and use of natural products in the form of raw materials, crude extracts, or isolated compounds to promote weight loss and thus control obesity [19].

The present study was conducted to evaluate the antihyperlipidemic activity of ethanolic and aqueous extracts of leaves of $A$. aspera by employing triton-induced hyperlipidemia model. The results were compared with atorvastatin. Ethanolic and aqueous extracts of leaves of $A$. aspera were found to be practically nontoxic and safe since it does not have any lethal effect even at a dose of $5000 \mathrm{mg} / \mathrm{kg}$ body weight when given orally to the adult female albino wistar rats.

In triton-induced hyperlipidemia model, triton produced a significant rise in serum TC and TG levels in hyperlipidemic control group. Ethanolic extract $(500 \mathrm{mg} / \mathrm{kg}$ ) produced a significant decrease in TC and TG levels. The present study shows that ethanolic extract of leaves of A. aspera found to have antihyperlipidemic activity on hyperlipidemic rats. However, it requires separation of the exact compound responsible for its antihyperlipidemic activity and further evaluation in different models and clinical studies is necessary to confirm the findings.

\section{ACKNOWLEDGMENT}

We are grateful to the management of Nitte Gulabi Shetty Memorial Institute of Pharmaceutical Sciences for providing the facility to carry out research work.

\section{REFERENCES}

1. Goyal BR, Goyal RK, Mehta AA. Phyto-pharmacology of Achyranthes aspera Linn: A review. Pharmacogn Rev 2007;1(1):143-50.

2. Ballantyne CM, Keefe JH, Gotto AM. Dyslipidemia Essentials Physicians. New York, New Delhi: Jaypee Press; 2003. p. 3-4, 60-74, 128.

3. Anand M, Selvaraj V, Alagar M. Phytochemical screening and evaluation of (in vitro) antioxidant activity of Achyranthes aspera Linn. root extract. Int J Pharm Pharm Sci 2014;6(2):197-9.

4. Harborne JB. Phytochemical Methods. London: Chapmann and Hall; 1973. p. 89.

5. Mazumber A, Basu SP, Saha BP, Mazumder R. Phytochemical observation on leaf of lagerstromia parviflora (Roxb). Anc Sci Life 2002;22(2):21-4

6. Ghosh MN. Fundamentals of Experimental Pharmacology. $3^{\text {rd }}$ ed. Kolkata: Hilton \& Company; 2005. p. 190-6

7. OECD. Guidelines for the Testing of Chemicals. Acute Oral Toxicity - Up-and-Down-Procedure (UDP). OECD 425. Paris: Organization for Economic Cooperation and Development; 2006.

8. Akhtar MS, Iqbal J. Evaluation of the hypoglycaemic effect of Achyranthes aspera in normal and alloxan-diabetic rabbits. J Ethnopharmacol 1991;31(1):49-57.

9. Vogel HG, Vogel WH, Scholkens BA, Sandew J, Miller G, Vogel WF. Drug Discovery and Evaluation. $2^{\text {nd }}$ ed. Berlin, New York: Springer, Verlag; 2002. p. 1103-6.

10. Schurr PE, Schultz JR, Parkinson TM. Triton induced hyperlipidemia in rats as an animal model for screening hypolipidemic drugs. Lipids 1971;7(1):68-73

11. Buccolo G, David H. Quantitative determination of serum triglycerides by the use of enzymes. Clin Chem 1973;19(5):476-82.

12. Werner M, Gabrielson DG, Eastman J. Ultramicro determination of serum triglycerides by bioluminescent assay. Clin Chem 1981;27(21):268-71

13. Annoni GG, Bottasso RM, Ciaci D, Donato MF, Tripoli A. Clinical investigation of triglycerides. J Res Lab Med 1982;9:115.

14. Allain CC, Poon LS, Chan CS, Richmond W, Fu PC. Enzymatic determination of total serum cholesterol. Clin Chem 1974;20(4):470-5.

15. Kumar V, Khan MM, Khanna AK, Singh R, Singh S, Chander R, et al. Lipid lowering activity of Anthocephalus indicus root in hyperlipidemic rats. Evid Based Complement Alternat Med 2010;7(3):317-22.

16. Friedewald WT, Levy RI, Fredrickson DS. Estimation of the concentration of low-density lipoprotein cholesterol in plasma, without use of the preparative ultracentrifuge. Clin Chem 1972;18(6):499-502.

17. Al-Zubairi A, Al-Habori M, Al-Geiry A. Effect of Catha edulis (khat) chewing on plasma lipid peroxidation. J Ethnopharmacol 2003;87(1):3-9.

18. Holmgren PR, Brown AC. Serum cholesterol levels of nondiabetic and streptozotocin-diabetic rats fed a high cholesterol diet. Artery 1993;20(6):337-45.

19. Khanna AK, Chander R, Singh C, Srivastava AK, Kapoor NK. Hypolipidemic activity of Achyranthus aspera Linn in normal and triton induced hyperlipemic rats. Indian J Exp Biol 1992;30(2):128-30.

20. Rohit KV, Thomas P. Herbal medicines used in the traditional Indian medicinal system as a therapeutic treatment option for overweight and obesity management: A review. Int J Pharm Pharm Sci 2014;6(2):40-7. 